\title{
Environmental education and the health risk question: how do we educate the educators working with this theme?
}

\author{
D. M. Bianchini Bonotto \\ Departamento de Educação, Instituto de Biociências, \\ UNESP, Rio Claro, Brazil
}

\begin{abstract}
Our society is presently seeing a trend of continuous increase of risk with severe consequences, especially those linked to environmental aspects. It has obligated us to reflect on this production and its effects, either positive or negative, and, after a long reflection, to think about the adopted model of civilization and the possibilities of changing such a model. The educational institution is among the social departments responsible for this revision process, since it represents one possibility to promote a more critical vision from society, providing it with tools needed for a more responsible action. However, schools are dominated by a traditional work, which does not allow for enough and proper attention to these relevant and current questions, and which involve a critical analysis of the conceptions and values established by our civilization, resulting in the present patterns of science-technology-society relations and their influence on the environment and health. Several research works have indicated a diversity of barriers that obstruct this necessary change. Since formal education plays an important role in the education of society for this theme, in this paper the possibilities and difficulty dealing with this problem are discussed, focusing on the question of teacher education, based on investigations related to teacher education programs for environmental education. The data collected show the urgency for introducing this theme in teacher training programs, taking into account the fact that educators have their own conceptions, values and attitudes that should be considered in these programs.

Keywords: environmental education, risk literacy, health education, teacher education programs.
\end{abstract}




\section{Introduction}

In our contemporary society, the growing number of scientific and technological activities has resulted in a series of new products and growing influences that affect the entire world and our lives. For instance, recent biotechnological processes have generated genetically modified foods that play a part in farming and supermarkets in several countries. At the same time, discussions about whether enough research has been conducted to indicate that environmental or health problems derivate from these processes are presented, showing other interests involved in these researches and the social nature of scientific activity, intrinsically linked to social, economic and political influences.

Through this question, ingenuous observers or consumers believe that these products mean an unquestionable benefit to society, and with this view, they can be interpreted as a sign of progress and welfare, with total confidence in the defenders and sellers of this technology and the products derived from it. For others, in a radical opposite position, these apparent benefits presented by scientific and technological "advances" are essentially negative and must be fought off.

In fact, dealing with this specific matter and many similar others, we are presently seeing a trend of continuous increase in environmental risks, many of them having severe consequences, which have obligated our society to reflect on these productions and products, with their positive and/or negative consequences, without yielding, as Kneller [1] points out, to a superficial optimism or a frenetic hostility.

Thus, the enhancement of the human action impact allowed for the idea of environmental risk, calling for efforts towards the assessment of these risks, at a certain point predictable by modeling and interpretative techniques.

However, neither the possibilities of these technical predictions are total nor these assessment processes are a question of scientific procedures only, because, on further reflection, evaluating them and our choices are also a question of a worldview and the model of society constructed from this view. Based on this broad approach, as Jacobi [2] stresses, we must think about the adopted model of society and the possibilities of changing such a model, participating in this change at individual and collective levels.

This calls for a society prepared for this task, and the educational institution is among the social departments responsible for this process, since it represents one possibility of promoting a more critical view from society, providing it with tools needed for a more responsible action related to such task. Environmental education should develop democratic forms of popular participation, thus allowing society to learn how to collectively fight for their rights, as well as be responsible for a more balanced and healthier environment, surpassing the limitations of waiting and confidentially obey the decisions taken by specialists and government agencies [3], either acting according to influences of the media or minor interests.

In terms of official proposals and curricular documents, these aims have been presented and have been made public around the world in the last decades. In the 
case of Brazil, in the late 90s the Brazilian Federal Board of Education proposed the inclusion of Environment and Health among the themes to be explored at the country's schools, indicating the need to deal with these issues at all school levels and through an interdisciplinary approach.

These documents show that these themes have great community relevance and, in order to be conveniently dealt with, it should not remain restricted to a single school discipline only. They also indicate that this educative work should deal not only with knowledge and skills content but also within a broader approach, with value content too, aiming at an education for citizenship.

However, in spite of these references and documents, schools are dominated by traditional work, which does not allow for enough and proper attention to these relevant and current questions. Several researches, focusing on different subjects, aspects of the teaching and learning processes, school and curricular politics, have indicated a diversity of barriers that obstruct this necessary change.

Clément et al [4] presented some preliminary results coming from pilot tests developed during the first year of the European project "Biology, Health and Environmental Education for better Citizenship", finding that teaching/learning related to "questions vives" in Biology, Health and environmental issues is confronted to very different ways of thinking depending on the socio-economic and cultural contexts of each country. These aspects must be considered when these issues are dealt with, which means a great challenge to educators, since there is non-familiarity of the teachers to deal with the value content in education as a whole [5], something necessary to deal with these cultural dimensions.

Dawson [6] pointed out that, despite the increasing importance of biotechnology topics in our society, it is not regularly taught in schools, stressing the desirability of awareness of the development and range of student's understandings and attitudes may lead to a more appropriate use of biotechnology curriculum materials and thus improved biotechnology education in schools.

Aikenhead [7] discussed the "science for all" versus "science for an elite" dilemma that has plagued Science and Technology Education throughout 150 years of science education's formal existence. He argued that, although the last one - the traditional vision of school science - has been the status quo all these years, the first, called by him as a humanistic-cultural approach, has experienced a renaissance since the World War II. It promotes practical utility, human values, and a connectedness with personal and societal issues. According to this author over the past 40 years a considerable amount of research has accumulated that now provides solid evidence for understanding the educational needs of students. However, he stressed the tension between educational soundness and political reality,

that can force us to compromise our choices when we confront non-rational realities such as historical precedence, pressure from universities, directives from professional interest groups, and science and technology teachers who hold preconceptions at odds with humanistic-cultural approach to school science (p.12). 
In accordance with this proposition, and specifically concerning the question of environmental risks, as Riechard [8], it has been pointed out that, despite the fact that the accurate perceptions of risk are necessary for the attainment of a risk-literate society, the public education system has been treated as a peripheral aspect of the risk policy process. So, practically no attention is given to the improvement of this task. It explains the findings of Vargas et al (2003), that, in a preliminary study about the productions found in the Educational Material Collection of an Environmental and Health Education Laboratory, indicated the occurrence of voids in preventive education approaches, such as the need to better integrate concerns about AIDS and reproductive health with healthy policies and actions.

Taking this situation into account, in this paper I intend to focus on the question of teacher education for environmental education (EE) in general, since the teacher is an essential element in the effective implementation of any innovation [10]. I focus on the question from data collected at two exploratory researches that investigated the teachers' learning in environmental education programs, pointing out aspects that can help those who intend to draw up proposals involving environmental risks in general and the health questions associated with them, considering that they are part of EE contents.

I agree with the authors who do not conceive of teacher education programs as limited to a transmission of knowledge and skills [11-13]. Teachers are not mere consumers of academic knowledge and proposals presented to them in preor in-service courses, because they are active knowledge-makers. Learning to teach is really a complex process involving affective, cognitive and ethical factors, amongst others [13]. Thus, teacher education also consists of an investigation problem, as it seeks to elucidate different aspects involved in this process. As a consequence, teacher education for a differentiated educational content, as shown in this paper, has led me into two exploratory researches, trying to find how the apprehension and incorporation of this content occurs.

These researches, in a qualitative approach [14], involved interventions carried out by myself. One intervention was directed towards a group of inservice teachers and the other towards pre-service teachers, during two teacher education programs that I carried out. In these programs, the teachers have some time to discuss basic topics of EE, using the remaining time to prepare and carry out their classes, seeking to incorporate those aspects.

My goal was to investigate the teachers' learning how to deal with basic topics of EE, and point out relevant aspects involved in apprehending and incorporating them in their classes. The data were collected from my field notes and all kinds of writing done by the teachers, such as their exercises, personal reflections and teaching plans.

After analyzing all the data, I could identify some key issues that I will now present by showing excerpts from the teachers' writing that illustrate them. In order to preserve their identity, teachers were identified by letters. 


\section{The novelty of the subject and the process of construction and reconstruction of knowledge about it}

The teachers had, in general, a traditional naturalist and conservationist model of $\mathrm{EE}$, having the basic aim at changing individual behavior, in which the structural causes of the environmental problems are presented as nonsocial or universal, and are unrelated to the underlying social forces [15].

The teachers demonstrated good acceptance of the exhibited conception of broad EE, in which the natural and cultural aspects interpenetrate in the composition of the environment, according to the following report:

The enlarged EE approach involving political, economic and social issues is clearer to me. There were some obscure aspects that I can say I understand now. For example, I did not know that social problems could be included in EE, or if it should only be treated by the Social Sciences; but I know it now (B).

Referring to the conceptions and value content of the environmental question, involving the Science-Technology-Society (STS) relations, a pre-service teacher that had reflected on the view of society-nature separation established by our present society wrote:

The [question] man-nature dichotomy has become very clear to me. I had not thought about this before (K.E.).

However, it was not easy for them to deepen their knowledge of this referential while dealing with the aspects focusing on beliefs and values involving STS relations and the environmental question. Pre-service teacher B.B. clearly explained to me his difficulty seeing the value within the general content of science classes, probably due to the fact that he was only prepared for the "traditional work" throughout his school life. In-service teacher R. identified and very clearly expressed the difficulty modifying her vision of a scientist (an unusual and special human being), according to the following report:

(...) I confess that I am still bound to the conception of a scientist as someone distant from the actual world (R).

This last report indicates a difficulty changing conceptions. Despite the fact that she understood the different conceptions, she shows us that it cannot be quickly modified by/after a discussion. A change depends on other factors and one discussion can mean only the beginning of the process.

Another moment that indicated the complexity of this process occurred when teachers prepared and developed their teaching plans. The in-service teachers exposed their difficulties leading their classes to aspects focusing the STS relations and the environmental question, as follows: 
Maybe I can not yet argue when an issue on how to accommodate development and the environment is raised (...) how to work with a society where the persons currently aim at jobs and a comfortable life so that the environment is not part of their own life proposals (L).

So as to exemplify these difficulties, one pre-service teacher focused on a theme related to medicinal plants, considering aspects of the conflict between the use popular knowledge of medicinal teas and medicines provided by the pharmaceutical industry. That teacher included a reflection "concerning the use of allopathic drugs and its possible replacement by home-made medicinal teas" in her plan. She also intended to deal with "the question of the marketing done by the big pharmaceutical companies" as one proposed discussion (P).

Despite the fact that it was laudable to present the controversy between the medicinal homemade teas use and the companies doing marketing, I have found a "dichotomist" approach to the question of the manufactured and homemade drugs while analyzing the entire teaching plan. The teacher proposed an appreciation and valuation of the homemade drugs and their relationship with and old tradition. As for the manufactured drugs, it was suggested "to think about their use/abuse and to recognize them as drugs" (in a bad sense), as a clear opposition. After analyzing the plan, I pointed out this problem to the teacher who agreed with me. However, since I did not observe the teachers' classes, I cannot confirm whether this dichotomist approach was actually changed.

Considering that the subject treated in the programs is filled with conceptions and concepts that can be deepened more and more [16], I think that such learning calls for a process of continuous construction and reconstruction of knowledge. Also, considering the novelty that this subject means to teachers and taking into account its importance to our society, its study requires an urgent education effort, by introducing it into initial and permanent teacher education programs, which have a design that allows us to follow the process of teachers' learning, which is difficult to do in factual and short time designs.

\section{Emergent feelings}

Another aspect that was captured in these research works refers to the feelings manifested during reflections on conceptions and values of society and the educative work to deal with them. The suggestion to modify traditional practices, dealing with a changing of conceptions and values to construct a new model of society is not an easy matter for teachers.

The discussions about the relationship between the environmental question and our society's capitalist and consumption model, as well as the deep proposals to change this model, caused discouragement and feelings of disbelief for the group of in-service teachers.

In their writing, they exhibited signs of insecurity and doubts after some discussions. This mainly occurred when they reflected on the intensity of the necessary changes and how our daily actions - personal and pedagogic - are distant from those considered more appropriate in terms of the presented 
referential. Some teachers also referred to their own values, which they had not clearly recognized before, as the following reports suggest:

The present-day activities showed how difficult it is to change. By the way, is it possible? I saw that all these things are already part of our culture and they represent a habit acquired before birth. I particularly adore technology, new things (...) (V).

The time at which we analyzed the content of poetries made me reflect on my own values, on the things that are actually relevant to my life (E. A. S. O.).

The reflections on environmental problems and the values and choices of our present model of society necessarily promote the examination of teachers' own values, which is not an easy matter. And as Aikenhead [7] pointed out, teachers' values, beliefs and ideologies must be in harmony before a teacher teaches subjects related to these aspects.

In the group of pre-service teachers, some of them clearly exposed their fear and insecurity of having an authoritarian attitude when dealing with the value content of the environmental question, as we can see in the following statement:

The values education is a difficult task, because sometimes we do what we cannot do. The education that I received imposed opinions on me, and then it is not easy for me to do it differently. (F.A.K)

I conclude that, besides knowledge, feelings must also be considered an important content of teacher education programs, and, consequently, they must be handled with care [17], having a confidence space to be showed and worked. This is another aspect to be properly addressed in teacher education programs concerning the theme, making it possible to work the anxieties arising from the aim of favoring the intended changing process. As Gayford and Dillon [18] pointed out, a simple preoccupation with knowledge and conceptual understandings denies the role of the emotions and the wider aspects of "knowing" should involve consideration of it too.

\section{The tendency to work with conceptual content}

When dealing with the need to work with ethical questions and the values content of environmental problems, practically all teachers agreed on the need to work with them at school, but the question about how to do it is not easy for them. Many pre-service teachers investigated here became surprised at the discussions involving the value content in educative work, as the following statement shows us:

I had never deeply thought about the values the teacher can pass on to their students and the way such theme may be worked. (M.F.G.) 
The difficulties understanding and dealing with the value content in the teaching and learning process, presented in the literature [19, 20], were clearly verified in these investigations, not only during the classes and written exercises, in which the issue was raised, but also in the teaching plans.

Practically all teaching plans had a tendency to emphasize conceptual content, and I had to indicate it to all teachers, encouraging them to look for the value content of the subjects they would teach.

When I assigned pre-service teachers a written exercise asking them to analyze their previous teaching plans (the ones they had prepared before our classes about values) and examine the value content of the subject matter they had intended to teach, some of them perceived the absence of specific propositions for this content.

They had difficulty detecting the values content of a theme, such as describing it in their plans. In some cases, concepts and understandings are presented as values, demonstrating that it is not clear for many of them what a concept, idea or fact is, and which values and valuations are linked to them. During the initial classes, pre-service teacher B.B. clearly explained to me his difficulty seeing the value within the general content of science classes, probably due to the fact he was only prepared to the "traditional work" in his school life.

Since the broader educative work that is necessary to handle the environmental question in its broad approach must deal with values subjacent to this, the difficulties teachers go through to deal with values must be considered; and teacher education programs have to place special attention to this aspect warning teachers of the tendency for this content to be forgotten - which can allow for a better incorporation of an intentional and specific educative work with the value content.

\section{Final considerations}

The data collected show the urgency for introducing themes related to EE in trainee teachers programs, since the traditional school is either distant from these actual needs or focus on them improperly. Educators generally have a lack of knowledge of theses matters, and are informed about them basically through the media. On the other hand, beyond the aspect of knowledge, the teachers' conceptions, values and attitudes, beliefs and disbeliefs (the ones they will bring into their practices, although sometimes they are hidden) must be considered in any training program.

Bearing in mind that the incorporation of an innovation in teacher practices does not occur automatically, the programs cannot contain only lectures, but also activities, discussions and enough time for teachers to try bringing the innovation into their practices even during the programs.

Finally, considering that there must be several other aspects not revealed by these exploratory research works stressed here and take up the question that there are several barriers that obstruct a change of traditional education and the traditional world view, I would like to finish these considerations about EE and 
the environmental health risk question, pointing out the need to consider in one way the complexity of cultural changing and in another its necessity.

Without exaggerated optimism or pessimism, I consider that it is important to recognize the limitations of this task of looking for its possibilities. In terms of research in the education field, that can illuminate the understanding of educational practices to help the proposal of more effective ones, I agree with the recommendations of Aikenhead [7], indicating that future projects, both on small-scale and large-scale, will need to manage the dynamics among research, policy, practice, and especially power".

\section{References}

[1] Kneller, G.F. A Ciência como Atividade Humana. Zahar Editora e EdUSP: Rio de Janeiro, 1994.

[2] Jacobi, P. Educar na sociedade de risco: o desafio de construir. CDRom of Anais do III EPEA, Ribeirão Preto, p. 1-15, 2005.

[3] Bonotto, D.M.B. The environmental education and the risk literacy: an approach to a healthy and sustainable society. Environmental Healthy Risk, eds. D. Fajzieva, \& C.A. Brebbia, WITPress: Southampton, pp. 247-256, 2001.

[4] Clémente, P.; Carvalho, G.; Abrougui, M.; Kkalil, I.; Thiaw, M.S.; Ndiaye and V.; Varga, A. Differences in values associated to biology, healthy and environmental questions among France, Portugal, Hungary, Senegal, Lebanon and Tunisia. Proceedings XII IOSTE Symposium, eds. S. Yoong; M. Ismail; A.N. Md. Zain; F. Salleh; F.S. Fook; L.C. Sam and M.N.L. Yan, Zillion Circle Ed.: Penang, 2006, pp.149-151.

[5] Bonotto, D.M.B. Understandings of the Science and Biology Trainee Teachers of the Value Content of Environmental Education and its Teaching. Proceedings XII IOSTE Symposium, eds. S. Yoong; M. Ismail; A.N. Md. Zain; F. Salleh; F.S. Fook; L.C. Sam and M.N.L. Yan, Zillion Circle Ed.: Penang, 2006, pp. 128-131.

[6] Dawson, V. An Exploration of High School (12-17 Year Old) Students' Understandings of, and Attitudes Towards Biotechnology Processes. Research in Science Education, 37, pp. 59-73, 2007.

[7] Aikenhead, G. The Humanistic and Cultural Aspects of Science and Technology Education. Eds. R.M. Janiuk \& E. Samonek-Miciuk, Science and Technology Education for a Diverse World. Maria Curie-Sklodowska University Press: Lublin, p.11-36, 2006.

[8] Riechard, D.E. Risk literacy: Is It the Missing in Environmental Education? The Journal of Environmental Education, v25, nº1, pp. 8-12, 1993.

[9] Vargas, E.; Monteiro, S.; Silva, F. and Cruz, M. AIDS and reproductive health: an analysis of the production of educational technology. Proceedings X IOSTE Symposium, eds. N. Bizzo; C.S. Kawasaki; L. Ferracioli and V.L. da Rosa, Foz do Iguaçu, v.1, pp. 199-208, 2002. 
[10] Nóvoa, A. Formação de professores e profissão doente. Ed. A. NÓVOA, Os professores e sua formação, Publicações Dom Quixote: Lisboa, pp.1533, 1992.

[11] Zeichner. A formação reflexiva de professores: idéias e práticas. Educa: Lisboa, 1993.

[12] Marcelo, C. Formação de professores para uma mudança educativa. Porto Editora: Porto, 1999.

[13] Mizukami, M.G.N.; Reali, A.M.M.R.; Reyes, C.R.; Lima, E.F.; Martucci, E.M.; Abib, M.L.V.S.; Mello, R.R. and Tancredi, R.M.S.P. A reflexão sobre a ação pedagógica como estratégia de modificação da escola pública elementar numa perspectiva de formação continuada no local de trabalho. Anais do IX ENDIPE, Lindóia, pp.490-509, 1998.

[14] Bogdan, R. \& Biklen, S. Investigação qualitativa em Educação: uma introdução à teoria e aos métodos. Porto Editora: Porto, 1994.

[15] Corcoran, P.B. \& Sievers, E. Reconceptualizing Environmental Education: Five Possibilities. The Journal of Environmental Education, v25, nº 4, pp.4-8, 1994.

[16] Zabala, A. A prática educativa: como ensinar. Artmed: Porto Alegre, 1998.

[17] Bonotto, Investigating an in-service program for elementary school teachers about the STS relations and the environmental problems, eds. R.M. Janiuk \& E. Samonek-Miciuk, Science and Technology Education for a Diverse World, Maria Curie-Sklodowska University Press: Lublin, p. 135-144, 2006.

[18] Gayford, C. \& Dillon, P. Policy and The Practice of Environmental Education in England: a dilemma for teachers. Environmental Education research, v1, no 2, pp.173-183, 1995.

[19] Halstead, J.M. \& Taylor, M.J. Learning and teaching about values: a review of recent research. Cambridge Journal of education, v.30, $\mathrm{n}^{\mathrm{o}} 2, \mathrm{p}$. 170-202, 2000.

[20] Levinson, R. Teaching ethical issues in Science. Proceedings X IOSTE Symposium, eds. N. Bizzo; C.S. Kawasaki; L. Ferracioli and V.L. da Rosa, Foz do Iguaçu, v. 2, p. 488-497, 2002. 